\title{
Detection of herpes simplex virus DNA in donor cornea culture medium by polymerase chain reaction
} David J Morris, Graham M Cleator, Paul E Klapper, Robert J Cooper,
Emmanuel O E Biney, Carol Dennett, Boris Marcyniuk, Andrew B Tullo in precipitating graft failure. We report a prospective study by virus isolation and the PCR of HSV infection in the organ culture media of 80 corneas.

\section{Materials and methods}

NORMAL DONOR CORNEAS

Eighty consecutive corneas from 48 cadaveric donors, none of whom had a prior history of herpetic eye disease, were prospectively selected from those issued by the David Lucas Manchester Eye Bank between December 1992 and March 1993. The procurement, processing, and organ culture of the corneas were performed according to standard aseptic protocols in a class II laminar flow cabinet by staff wearing sterile gloves, masks, and gowns. ${ }^{5}$ Eyes trimmed of all adherent conjunctiva and fat were immersed successively in $5 \%(w / v)$ polyvinylpyrolidone-iodine (aqueous Betadine, Napp Laboratories, Watford) for 4 minutes and $0.3 \%(\mathrm{w} / \mathrm{v})$ sodium thiosulphate for 30 seconds before three washes in normal saline. The corneas together with a 2-3 $\mathrm{mm}$ rim of sclera were excised and suspended, via a suture, in $60 \mathrm{ml}$ of culture medium (Eagle's minimal essential medium with Earle's salts containing 2\% (v/v) fetal calf serum (FCS), $20 \mathrm{mM}$ HEPES buffer, $24 \mathrm{mM}$ sodium bicarbonate, $2 \mathrm{mM}$ L-glutamine, $100 \mathrm{IU} / \mathrm{ml}$ penicillin $\mathrm{G}, 0.1$ $\mathrm{mg} / \mathrm{ml}$ streptomycin sulphate, and $0.24 \mu \mathrm{g} / \mathrm{ml}$ amphotericin B). The tissues were incubated at $34^{\circ} \mathrm{C}$ for a minimum of 10 days, and issued for transplantation as an excised $8 \mathrm{~mm}$ diameter corneal button when (1) the bacterial and fungal cultures on medium collected 8 days after initial processing and 1 day before issue both proved negative, and (2) trypan blue staining 2 days before issue revealed a minimal endothelial cell count of 2000 cells $/ \mathrm{mm}^{2}$. other than the testing of spent culture medium Cadaveric donors have the high prevalence of low level HSV antibodies typical of the general population, ${ }^{1}$ but $\mathrm{HSV}$ shedding from the eye or pharynx is very rare. $^{12}$ Although HSV DNA is present in cadaver corneal tissues ${ }^{13}{ }^{4}$ monitoring of donor corneas for HSV DNA using the polymerase chain reaction (PCR) is precluded by the destructive nature of tissue processing for this assay. False negative and false positive results may arise if only the residual scleral rim is tested. ${ }^{14}$ None the less, it is important to establish whether healthy corneas develop active HSV infection in organ culture as a prelude to further investigation of the role of HSV
PROCESSING OF CORNEAL ORGAN CULTURE MEDIUM

Following removal of the cornea from the culture vessel for transplantation, the residual culture medium was submitted for examination using virus isolation in cell culture for infectious HSV and the PCR for HSV DNA. Neat medium $(50 \mathrm{ml})$ was centrifuged at $1850 \mathrm{~g}$ for 5 minutes to separate the cell pellet and the supernatant fluid. Any cell free $\mathrm{HSV}$ or its DNA was precipitated from the supernatant fluid by overnight incubation at $4^{\circ} \mathrm{C}$ with $7 \mathrm{ml}$ $5 \mathrm{M}$ sodium chloride and $8 \mathrm{ml} 50 \%(\mathrm{w} / \mathrm{v})$ 
polyethylene glycol (PEG) 8000 followed by centrifugation at $1850 \mathrm{~g}$ for 10 minutes. ${ }^{6}$ The cell pellet and the cell free PEG precipitate were resuspended in $800 \mu \mathrm{l}$ or $600 \mu \mathrm{l}$ respectively of Eagle's minimal essential medium.

\section{VIRUS ISOLATION}

Aliquots of each neat medium, resuspended cell pellet and resuspended PEG precipitate were inoculated onto three monolayer cultures of Vero cells in multiwell plastic cell culture trays using centrifugal enhancement of adsorption ( $3500 \mathrm{~g}$ for 15 minutes at room temperature) for all preparations except the cell pellets. The Vero cells were propagated in growth medium (Eagle's minimal essential medium supplemented with $10 \%$ FCS, $0.1 \mathrm{mM}$ L-glutamine, $100 \mathrm{IU} / \mathrm{ml}$ penicillin $\mathrm{G}$, and 100 $\mu \mathrm{g} / \mathrm{ml}$ streptomycin). The inoculated cell cultures were incubated at $37^{\circ} \mathrm{C}$ in $5 \%$ carbon dioxide for 28 days in maintenance medium (Eagle's minimal essential medium supplemented with $1 \%$ FCS, $0.1 \mathrm{mM}$ L-glutamine, $100 \mathrm{IU} / \mathrm{ml}$ penicillin, and $100 \mu \mathrm{g} / \mathrm{ml}$ streptomycin) before being discarded as negative. The cell monolayers were examined daily for the appearance of HSV cytopathic effects.

\section{HSV AND HUMAN $\beta$-GLOBIN PCRS}

The residual cell pellets and cell free PEG precipitates were stored at $-20^{\circ} \mathrm{C}$ between inoculation of Vero cell cultures and PCR testing. The DNA was prepared for PCR amplification by incubation with $0.5 \%(\mathrm{w} / \mathrm{v})$ sodium dodecyl sulphate (SDS), and $250 \mu \mathrm{g} / \mathrm{ml}$ proteinase $\mathrm{K}$ at $37^{\circ} \mathrm{C}$ for 2 hours, phenol chloroform extraction, and ethanol precipitation. The pellets were dissolved in $1 \times$ TE buffer ( $10 \mathrm{mM}$ TRIS hydrochloric acid, $1 \mathrm{mM}$ ethylenediaminetetra-acetic acid (EDTA) $\mathrm{pH} \mathrm{8.0)}$ before DNA amplification.

Primers n7 (5'-CGCGCGGTACCTTATGGGCAGCATGA-3') and n8c (5'-CAGGGTAAATAACGTGTCCCCGATATGG-3') amplified a 350 base pair fragment of the HSV thymidine kinase gene (detection limit 5 plaque forming units of $\mathrm{HSV}^{7}$ ) whereas primers PC 04 (5'-CAACTTCATCCACGTTCACC-3') and GH20 (5'-GAAGAGCCAAGGACAGGTAC-3') amplified a 268 base pair fragment of the human $\beta$-globin gene (detection limit less than $10 \operatorname{copies}^{9}{ }^{10}$ ). Sterile distilled water (SDW) as contamination control or extracted DNA samples $(5 \mu \mathrm{l})$ were added to $45 \mu \mathrm{l}$ reaction mixture $(10 \mathrm{mM}$ TRIS-hydrochloric acid $\mathrm{pH} 8.3,50 \mathrm{mM}$ potassium chloride, $2 \mathrm{mM}$ magnesium chloride, $0.02 \%(\mathrm{w} / \mathrm{v})$ gelatin, $0.2 \mathrm{mM}$ each deoxy-

Table 1 Transplant outcome in recipients of donor corneas positive for HSV DNA in spent culture medium

\begin{tabular}{lllll}
\hline $\begin{array}{l}\text { Recipient } \\
\text { No }\end{array}$ & Sex & $\begin{array}{l}\text { Age } \\
\text { (years) }\end{array}$ & Diagnosis & Outcome \\
\hline 1 & M & 54 & $\begin{array}{l}\text { Keratoconus } \\
\text { Pseudophakic bullous } \\
\text { keratopathy }\end{array}$ & $\begin{array}{l}\text { Graft clear at 14 months } \\
\text { Graft failure at 7 months } \\
\text { due to vitreous touch } \\
\text { Graft clear at 18 months }\end{array}$ \\
3 & F & 82 & Ocular surface disorder & \\
\hline
\end{tabular}

nucleotide, $0.1 \mu \mathrm{M}$ appropriate primers, and 2.5 units Amplitaq DNA polymerase (PerkinElmer-Cetus, Emeryville, CA, USA), and evaporation was minimised by an overlay of two drops $(50 \mu \mathrm{l})$ of mineral oil. Thermal cycles on a Techne PHC-1 thermocycler comprised 7 minutes at $94^{\circ} \mathrm{C}$ before 50 cycles of 2 minutes at $94^{\circ} \mathrm{C}, 1.5$ minutes at $50^{\circ} \mathrm{C}$, and 2 minutes at $70^{\circ} \mathrm{C}$. The amplification product was visualised by ethidium bromide staining of DNA bands separated on agarose gel electrophoresis. Rigorous precautions to prevent exogenous contamination of the DNA extracts or PCR reaction mixtures with $\mathrm{HSV}$ or its DNA included separate rooms for preparation of reaction mixtures and preparation of and addition of DNA extracts, addition of DNA extracts within a Genesphere (Solotec Ltd, Cambridge), and a third room for product analysis. Plugged pipette tips were used throughout and the operator wore a face mask and gloves. ${ }^{1011}$ The contamination control included in each HSV and $\beta$-globin PCR run always gave a negative result.

\section{Results}

VIRUS ISOLATION

None of the organ culture media obtained from 80 corneas yielded HSV in Vero cell culture following separate inoculation of neat medium, cell pellet, and PEG precipitate.

\section{HSV AND HUMAN $\beta$-GLOBINS PCRS}

Three $(3.8 \%)$ of the 80 cell pellets from corneas issued for grafting were positive for HSV DNA by PCR. To confirm the presence of HSV DNA in the culture media from which the three HSV DNA positive cell pellets were prepared, PEG precipitates of cell free supernatants from the same three and two other randomly selected culture media were examined using the HSV DNA amplification assay. Positive results were obtained with PEG precipitates of cell free organ culture medium from the three corneas previously positive when cell pellets were tested, but not with the other two samples.

Human DNA amplifiable by PCR was present in most $(75(94 \%))$ of the DNA extracts prepared from the 80 corneal cell pellets subjected to HSV DNA amplification. The absence of human cellular DNA from all five PEG precipitates of cell free medium tested by HSV PCR was confirmed by negative results in the $\beta$-globin DNA amplification assay.

\section{TRANSPLANT OUTCOME}

All three corneas where the cell pellets and cell free PEG precipitates prepared from spent organ culture medium subsequently shown to contain HSV DNA were issued for transplantation. None had shown unacceptable endothelial cell loss when subjected to trypan blue staining and microscopic examination after organ culture. Table 1 illustrates the clinical outcome of the three recipients of these grafts. None developed primary graft failure or herpes simplex eye disease. 


\section{Discussion}

The existence of latent HSV infection within the human cornea is currently a matter of debate. ${ }^{11}{ }^{12}$ Studies utilising organ culture and PCR respectively identified infectious $\mathrm{HSV}$ or HSV DNA in corneal tissue. ${ }^{13413-18}$ The procedures used were not, however, able to distinguish persistent from latent infection. Japanese workers considered the existence of latent HSV infection of the cornea to be proved when their experimental definition for virus latency was satisfied. ${ }^{19}$ None the less, their experiments did not differentiate latent corneal infection from low level virus persistence. ${ }^{12}$ Latent infection of the ophthalmic division of the trigeminal ganglion could result in periodic reactivations of the virus from this site. Frequent reactivations might lead to the continuous presence of the virus in the cornea. ${ }^{112}$

We failed to isolate infectious HSV and only rarely amplified HSV DNA from corneal organ culture media despite the use of sensitive culture and PCR techniques and effective procedures for the concentration of both cell associated and cell free virus. The high $\beta$-globin PCR positivity rate with the material pelleted from the culture media by low speed centrifugation suggested that most corneas in culture shed cells. Moreover, all five PEG precipitates of supernatant fluid were negative for human DNA by PCR, implying that the cells in corneal organ culture medium were successfully concentrated by low speed centrifugation. Also, three of these precipitates were HSV PCR positive, an observation compatible with efficient concentration of any cell free virus by PEG. Precipitation using PEG proved as effective as ultracentrifugation for concentration of dilute suspensions of human cytomegalovirus from urine specimens, and had the advantage of concentration of viral DNA. ${ }^{6}$

There were several possible explanations for the few HSV PCR positive virus culture negative results on cell pellets of organ culture media. Firstly, the media, DNA extracts, or PCR mixtures might have been contaminated with exogenous virus or DNA when the corneas were in reality free of HSV and its DNA. The three positive and two negative HSV PCR results obtained with both cell pellets and cell free PEG precipitates derived from the same culture media, and the negative results with a contamination control in every PCR run made contamination of culture media, DNA extracts, or PCR mixtures after the receipt of the culture media in the virology laboratory unlikely. The risk of contamination of the corneal cultures during processing at the eye bank was minimised by the techniques used. ${ }^{1}$ Other explanations for the viral DNA positive infectious virus negative results included false negative virus culture experiments, the presence of inactivated virus, or latent virus infection manifest as shedding of viral DNA but not infectious virus. The first of these was implausible given the high sensitivity of Vero cells for primary isolation of HSV and the almost certain absence of interfering virus neutralising antibodies in the culture media which contained only fetal calf and not human serum. However, the true explanation remained elusive given the controversy surrounding the existence of latent $\mathrm{HSV}$ in the cornea.

If the DNA positive culture negative results in this study reflected possible latent corneal infection, positive PCR tests on corneal culture media could have provided a marker for such latent infection. The reported prevalence of apparently latent $\mathrm{HSV}$ infection in human corneas varied widely in previous studies. Organ culture experiments suggested persistent or possibly latent infection in up to $67 \%$ of human corneas from patients with chronic stromal keratitis. ${ }^{1316}$ Polymerase chain reaction studies gave positivity rates of eight (73\%) or four (36\%) of 11 in corneas from patients transplanted for herpes keratitis or pseudophakic corneal oedema, ${ }^{17}$ and in one $(3 \%)$ of $32,{ }^{18}$ five $(50 \%)$ of $10,{ }^{3}$ three $(30 \%)$ of $10,{ }^{1}$ or $10(42 \%)$ of $24^{4}$ cadaver corneas. This large range of reported prevalences of arguably latent HSV infection in donor corneas could not be explained by the choice of PCR technique. One of the three studies employing only one set of $\mathrm{PCR}$ primers ${ }^{3}$ gave at least as high a positivity rate $(50 \%)$ as that using a possibly more sensitive nested protocol $(42 \%)$. However, different prevalences of covert previous herpes simplex eye disease in the corneas considered suitable for transplantation in the four centres cannot be excluded. Therefore, we do not know whether the relatively low rate of HSV PCR positivity in corneal organ culture media in the present study suggested the true prevalence of latent HSV infection in the donor corneas selected or in reality underestimated that prevalence. Failure to remove PCR inhibitors during DNA extraction was a possible cause of the low positivity rate for the HSV DNA with the cell pellets derived from corneal organ culture media. Most of the extracts were positive for $\beta$-globin DNA. However, the residual activity inhibitory to Taq polymerase in the extracts could have been insufficient to prevent successful amplification of relatively large quantities of human DNA even if detection of low concentrations of HSV DNA was rendered impossible.

Routine monitoring for infectious HSV of organ culture medium from corneas being stored before issue for transplantation seems difficult to justify in the absence of positive results. Active HSV infection may cause very rare episodes of severe corneal endothelial cell destruction during organ culture, ${ }^{1}$ but affected corneas should be identified by microscopic examination and discarded. Primary failure has been described in a corneal graft with an acceptable endothelial cell count after storage when gross endothelial cell necrosis was identified in the fellow cornea from the same donor. However, this combination of events is also probably exceptional, and would not of itself justify monitoring of the organ culture media of all donor corneas for infectious HSV. Testing of similar material for HSV DNA using the PCR would merely identify a few latently infected corneas (if such infection exists) and document rare instances of HSV transmission by corneal transplantation (if this event oc- 
curs). The low rate of positivity for HSV DNA in spent culture media from donor corneas is consistent with the fact that ocular herpes has been described following penetrating keratoplasty only rarely in patients with no preoperative history of this disease. ${ }^{2021}$ The incidence of primary graft failure following corneal transplantation ${ }^{22}$ is similar to the prevalence of HSV PCR positivity $(3.8 \%)$ in spent corneal organ culture medium in the present study. Though trauma to the cornea during retrieval, handling, storage, or transplantation, and in particular poor eye bank $k^{23}$ or surgical technique, ${ }^{22}$ may be the major causes of primary graft failure, a role for HSV cannot be excluded. None the less, detection of HSV DNA in a corneal organ culture medium could not at present be used as an indication for discarding the donor cornea. In this study none of the three recipients of HSV DNA positive corneal grafts has developed clinical consequences attributable to $\mathrm{HSV}$ at up to 18 months after transplantation.

We are grateful to Ms Pamela Gregory for assistance with the preparation of this manuscript.

1 Cleator GM, Klapper PE, Dennett C, Sullivan AL, Bonshek $\mathrm{RE}$, Marcyniuk B, et al. Corneal donor infection by herpes simplex virus: herpes simplex virus DNA in donor corneas. Cornea 1994;13:294-304

2 Kaye SB, Madan N, Dowd T, Hart C, McCarthy K, Patterson A. Ocular shedding of herpes simplex virus. $B r f O p h-$ thalmol 1990;74:114-6.

3 Kaye SB, Lynas C, Patterson A, Risk JM, McCarthy K, Hart CA. Evidence for herpes simplex viral latency in the human cornea. Br f Ophthalmol 1991;75:195-200.

4 Openshaw H, McNeill J, Lin XH, Niland J, Cantin OM. Herpes simplex virus DNA in normal corneas: persistence without viral shedding from ganglia. $f$ Med Virol 1995;46: 75-80.

5 Ridgway AE, Marcyniuk B. The UK cornea transplant service and the establishment of the David Lucas Manchester Eye Bank. Dev Ophthalmol 1991;22:44-9.

6 Kimpton CP, Corbitt G, Morris DJ. Comparison of polyethylene glycol precipitation and ultracentrifugation for recovery of cytomegalovirus from urine prior to detection of DNA by dot-blot hybridisation. $\mathcal{F}$ Virol Methods 1990;28:141-6.

7 Klapper PE, Cleator GM, Dennett C, Lewis AG. Diagnosis of herpes encephalitis via Southern blotting of cerebrospinal fluid DNA amplified by the polymerase chain reaction. F Med Virol 1990;32:77-82.

8 Dennett C, Klapper PE, Cleator GM, Lewis AG. CSF treatment and the diagnosis of herpes encephalitis using the polymerase chain reaction. 7 Virol Methods 1991;34:101-4.

Bauer HM, Ting Y, Greer CE, Chambers JC, Tashiro CJ, Chimera J, et al. Genital human papillomavirus infection in female university students as determined by a PCR-based method. FAMA 1991;265:472-7.

10 McElhinney LM, Cooper RJ, Morris DJ. Multiplex polymerase chain reaction for human herpesvirus-6, human cytomegalovirus, and human $\beta$-globin DNA. $千$ Virol Methods 1995;53:223-33.

11 Cook SD, Hill JH. Herpes simplex virus: molecular biology and the possibility of corneal latency. Surv Ophthalmol 1991;36:140-8.

12 Gordon YJ, Romanowski E, Araullo-Guz T, McKnight JLC. HSV-1 corneal latency. Invest Ophthalmol Vis Sci 1991;32: 663-5.

13 Shimeld C, Tullo AB, Easty DL, Thomas J. Isolation of herpes simplex from the cornea in chronic stromal keratitis. $\mathrm{Br}$ pes simplex from the cornea

14 Tullo AB, Easty DL, Shimeld C, Stirling PE, Darville JM. Isolation of herpes simplex virus from corneal discs of patients with chronic stromal keratitis. Trans Ophthalmol Soc UK 1985;104:159-64.

15 Coupes D, Klapper PE, Cleator GM, Bailey AS, Tullo AB. Herpes virus simplex in chronic human stromal keratitis. Curr Eye Res 1986;5:735-8.

16 Easty DL, Shimeld C, Clauoe CMP, Menage M. Herpes simplex virus isolation in chronic stromal keratitis: human and laboratory studies. Curr Eye Res 1987;6:69-74.

17 Cantin EM, Chen J, McNeill J, Willey DE, Openshaw H. Detection of herpes simplex virus DNA sequences in corneal transplant patients by polymerase chain reaction corneal transplant patients by polymerase

18 Crouse C, Pflugfelder SC, Pereira IE, Cleary J, Rabinowitz $S$, Atherton S. Detection of herpes viral genome in normal S, Atherton S. Detection of herpes viral genome in normal and.

19 Shimomura Y, Mori Y, Inoue Y, Kiritooshi A, Ohashi Y, Masabe $R$. Herpes simplex virus latency in human cornea. Fpn f Ophthalmol 1993;37:318-24.

20 Salisbury JD, Berkowitz RA, Gebhardt BM, Kaufman HE. Herpes virus infection of corneal allografts. Ophthalmic Surg 1984;15:4058-60.

21 Beyer CF, Byrd TJ, Hill JM, Kaufman ME: Herpes simplex virus and persistent epithelial defects after penetrating keratoplasty. Am $\mathcal{f}$ Ophthalmol 1990;109:95-6.

22 Mead MD, Hyman L, Grimson R, Schein OD. Primary graft failure: a case control investigation of a purported graft failure: a case control in.

23 Buxton JN, Seedor JA, Perry HD, Eagles RC, Pecego JA. Donor failure after corneal transplantation. Cornea 1988;7: 89-95. 